\title{
20. SULFUR DISTRIBUTION IN HOLES 380 AND 380A OF LEG 42B
}

\author{
Robert A. Berner and George R. Holdren, Jr., Department of Geology and Geophysics, \\ Yale University, New Haven, Connecticut
}

\section{INTRODUCTION AND METHODS}

This study was undertaken with the original intention of determining the concentrations of the various forms of reduced sulfur (black FeS, elemental sulfur, organic sulfur, and pyrite) using the techniques described earlier (Berner, 1974) and to measure the sulfur isotopic composition of each form. Unfortunately neither goal could be achieved. Although only frozen samples were collected, they had not withstood air oxidation during storage. For example, samples described in the shipboard log as "black shale" (from Cores $76,77,78$, and 80 ) were brownish gray in color when collected frozen at the Woods Hole Oceanographic Institution in April of 1976. Change of color from black to brown indicates the oxidation of black, pigmenting FeS minerals (greigite, mackinawite) to brown ferric oxides. In better condition was the black mud at the top of Site 380 which was partly black but, nevertheless, oxidized on the outer surface of the frozen chunks. It is suggested that the relatively low water content of all deeper samples (below about $50 \mathrm{~m}$ ) was insufficient to form a solid protective ice coating over all potentially oxidizable sediment grains. The near-surface sample, by contrast, contained sufficient water that freezing provided protection and oxidation occurred only around the outer margin. At any rate, because of oxidation, analyses for black FeS (which is easily oxidized by air) or elemental sulfur (which is formed by the air oxidation of $\mathrm{FeS}$ ) were not done.

Total sulfur, which is unaffected by air oxidation, was determined on 16 samples. The samples were obtained frozen in sealed plastic bags from Dr. John Hunt of Woods Hole Oceanographic Institution and were transported back to Yale University packed in dry ice. They were kept frozen in a freezer at Yale until analysis. For the analysis the samples were dried overnight in an oven at $82^{\circ} \mathrm{C}$, ground in an agate mortar, and dried to constant weight in a vacuum desiccator. The sedimentary sulfur was oxidized by combustion in a LECO model 521 induction furnace to $\mathrm{SO}_{2}$ plus $\mathrm{SO}_{3}$ and then converted to dissolved sulfate ion by trapping in a 3\% hydrogen peroxide solution. The sulfate was then precipitated as barium sulfate and the $\mathrm{BaSO}_{4}$ determined gravimetrically. Pyrite and galena of known sulfur content were used as standards. Yields for this procedure average $82 \%$.

\section{DISCUSSION AND CONCLUSIONS}

Results of the analyses are expressed in terms of percent sulfur by dry weight in Table 1. Except for Samples 380A-1, CC and 380A-5-4B, the relatively high
TABLE 1

Total Sulfur in Per Cent Dry Weight in Hole 380 and $380 \mathrm{~A}$ of DSDP Leg 42B, the Black Sea

\begin{tabular}{|c|c|c|}
\hline Sample & Depth (m) & $\begin{array}{c}\% \text { Sulfur } \\
\text { by Dry Weight }\end{array}$ \\
\hline \multicolumn{3}{|l|}{ Hole 380} \\
\hline $\begin{array}{l}0 \text {-top } \\
19-4\end{array}$ & $\begin{array}{r}0 \\
177\end{array}$ & $\begin{array}{l}0.32 \\
1.15\end{array}$ \\
\hline \multicolumn{3}{|c|}{ Hole $380 \mathrm{~A}$} \\
\hline $\begin{array}{l}1, \text { CC } \\
5-4-B \\
32-0 \\
36, \text { CC } \\
40, \text { CC } \\
41-0 \text {-top } \\
41-3-\text { B } \\
42-0 \text {-top } \\
42, \text { CC-B } \\
57, \text { CC } \\
76, \text { CC } \\
77-1 \\
78, \text { CC-B } \\
80-1-40 \\
\end{array}$ & $\begin{array}{r}333 \\
375 \\
618 \\
656 \\
694 \\
703 \\
706 \\
713 \\
713 \\
855 \\
1036 \\
1046 \\
1055 \\
1075 \\
\end{array}$ & $\begin{array}{l}0.06 \\
0.01 \\
0.25 \\
0.27 \\
0.23 \\
0.34 \\
0.19 \\
0.56 \\
0.69 \\
1.36 \\
1.70 \\
1.26 \\
1.50 \\
1.19 \\
\end{array}$ \\
\hline
\end{tabular}

values shown represent primarily reduced forms of sulfur or, in other words, all forms of sulfur other than sulfate. The amount of sulfate present in the interstitial water of the sediments could provide at most about $0.1 \% \mathrm{~S}$ by dry weight. This means that bacterial sulfate reduction, the ultimate process responsible for most of the reduced sulfur (see Ostroumov, 1953; Volkov, 1961; Kaplan et al., 1963), has been effective over much of the history of the Black Sea represented by Holes 380 and 380 A. Since bacterial sulfate reduction occurs only under anaerobic conditions, and is most effective during early diagenesis, this means the anoxic pore waters were present in the sediments during much of this history. More intense sulfate reduction occurred in sediments now buried below 800 meters where total sulfur exceeds $1 \%$ by dry weight, a value typical of modern deep Black Sea sediments (Volkov, 1961). By contrast, over the depth interval 600-800 meters, sulfur values reported here range from $0.2 \%$ to $0.7 \%$ sulfur suggesting lower rates of sulfate reduction due to lower rates of deposition of organic matter (Goldhaber and Kaplan, 1975). Sediments in this depth range may not have been deposited under totally anoxic conditions in that some of the reduced sulfur could have formed in micro-environments about discrete masses of decaying organic matter.

A high density of sampling occurs over the interval 615 to 715 meters. The reason for this is the report in 
the shipboard log of abundant siderite. We sought to isolate and identify positively this siderite but could not find it. If it were originally present, it must have been oxidized away prior to our sampling. From the brownish color of the samples at the time of sampling and the observations of Seguin (1966) of rapid siderite oxidation in air, it is not unlikely that siderite destruction by oxidation did occur in these samples.

\section{ACKNOWLEDGMENTS}

We are indebted to Dr. John Hunt for supplying to us frozen samples from which our analyzed samples were taken. Research was supported by NSF Grant DES 73-00411.

\section{REFERENCES}

Berner, R.A., 1974. Iron sulfides in Pleistocene deep Black Sea sediments and their paleo-oceanographic significance.
In The Black Sea: Am. Assoc. Petrol. Geol. Mem. 20, p. $524-531$.

Goldhaber, M.B. and Kaplan, I.R., 1975. Controls and consequences of sulfate reduction rates in recent marine sediments: Soil Sci., v. 119, p. 42-55.

Kaplan, I.R., Emery, K.O., and Rittenberg, S.C., 1963. The distribution and isotopic abundance of sulfur in recent marine sediments off southern California: Geochim. Cosmochim. Acta, v. 27, p. 297-331.

Ostroumov, E.A., 1953. Different forms of combined sulfur in the sediments of the Black Sea: Trudy Inst. Okeanol. Akad. Nauk. SSSR, v. 7, p. 70-90.

Seguin, M., 1966. Instability of $\mathrm{FeCO}_{3}$ in air: Am. J. Sci., v. 264 , p. $562-568$.

Volkov, I.I., 1961. Iron sulfides, their interdependence and transformation in the bottom sediments of the Black Sea: Trudy Inst. Okeanol. Akad. Nauk. SSSR, v. 50, p. 68-92. 